\title{
A KNIFE TO A GUNFIGHT: ENDOGENOUS DEVELOPMENT THROUGH LEADER AS CONTRADICTORY POLICY PRESCRIPTION
}

\author{
GEORGE IULIAN ZAMFIR ${ }^{1}$
}

\begin{abstract}
By now a preferred EU instrument aimed at stirring rural development, LEADER initially constituted an alleged departure from the top-down productivist agenda of the CAP towards locally-led development. The exogenous-endogenous explanatory model legitimized the adoption of economistic assumptions into EU rural development policy. As the CAP policy genealogy conveys, agricultural policies occurred at the intersection of internal and external factors, whereas the endogenous framework evicts structural explanations for territorial marginalization. A case study from North-western Romania provides details on the implementation of the endogenous agenda from the perspective of public actors. Rather than inducing an alleged alternative development model, LEADER acts as adjuvant to other policies and, overall, as a pedagogical exercise in uneven development.
\end{abstract}

Keywords: Common Agricultural Policy, LEADER, rural development, exogenous-endogenous debate

\section{Introduction ${ }^{2}$}

The pandemic driven Economic Recovery Pack presented by the EC President von Layen in late May 2020 represents an unforeseen discursive „reinforcement” of Rural Development Policy as key policy, after the January discussions on the next budget period pointed to funding cuts. After the risks of uninterrupted endless economic growth have been illuminated by the lockdown imposed during the pandemic, the degrowth paradigm resurfaces as an even more compelling alternative.

\footnotetext{
1 Faculty of European Studies, Babeș-Bolyai University, e-mail: george7zamfir@gmail.com.

2 This research has been funded through the comparative research project "RELOCAL. Resituating the Local in Cohesion and Territorial Development"; www.relocal.eu.
} 
Rural development has long been designated an economic problem and is still treated as such by EU policy. While to some extent it represents a valid proposition, economic thinking has taken over other areas of intervention and reduced most aspects of social life to the discipline's specific assumptions. Exogenous and endogenous thinking, the latter a heuristic device increasingly applied to economic models in the 1980s (Romer, 1994: 3), was transferred to rural development policies. A Trojan horse, as Somers (2005) puts it, social capital and its variations made their way in social theories and inherently supported the reinforcement of economistic legitimacy. Although it led to the production of a significant body of rich analyses of rural processes, most tackled the efficacy of the Common Agricultural Policy (hereinafter CAP) and even when some of its assumptions have been laid out, its origins have been naturalized.

The argument is that dereliction of European countryside has been conflated with a specific type of economic problematization. LEADER is an example of persistent portrayal of rural development as economically unsuccessful because it lacks the required growth oriented structures, particularly the lack of coordination. However, while some 'successes' of LEADER can justifiably be claimed, and the endogenous ontology alludes to progressive approaches, the structure and overall context of the action will not lead to solutions to the deemed rural problems, if the endless growth model and contradictory upper level policies continue. Worrying, the 2014-2020 cycle has further mainstreamed the model to territorial policies without proper acknowledgment of its questionable assumptions.

The article departs with an overview of the history of the CAP and its driving factors. It continues with a critical take on the principles of LEADER, particularly the origins and implications of the exogenous-endogenous debate. Next, drawing on a case study part of the Relocal.eu project focused on perceptions of spatial justice among stakeholders surrounding a Local Action Group (LAG) in North-western Romania, the article supplies observations on where and how endogenous practice fails.

\section{The CAP - assessments of its continuity and fragmentation}

The history of the CAP has been the subject of numerous thorough studies (e.g. Lynggaard 2006). Several points, however, are worth mentioning here, particularly in respect to some of the policy drivers shaping the role of LEADER. The European project enshrined agriculture as a key focus in the Treaty of Rome in 1957 when concerns of food insecurity determined by World War 2 were still looming. Moreover, the Commission's proposal in 1960 underlined 
the need to protect the internal market from fluctuating world markets (Feindt, 2018), turning it into an exceptionalist policy. What makes agricultural policy special in the EU is its continuity and its main actors' aversion to change. A three decades old debate lingers on if and how the CAP has shifted from its original dominant productivist principle towards a post-productivist (Mather, Hill and Nijnik, 2006; Almstedt et al., 2014), or to a neo-productivist phase (Pelucha and Kveton, 2017), as well as if it exerts signs of a post-exceptionality era (Greer, 2017; Daugbjerg and Feindt, 2017). Definite conclusions depend on the assessment of variables such as the policy community influence, the overall changes in the EU mechanisms and the impact of global contexts. In a twist of events, "[d]uring the post-productivist era the main threats to the countryside are generally perceived to be agriculture itself rather than urban or industrial development" (Wilson, 2006: 4). Simultaneously, pleas for a shift to a degrowth paradigm are on the rise (Hickel, 2017; Gerber, 2020).

Income support for agricultural producers remains the primary objective of the CAP, with others stuck in a secondary position (Feindt, 2018: 121). Continuity of the CAP has been safeguarded by its sectoral character, which transformed it into a domain controlled by club-like policy circles which enforced its path-dependency. Change has been difficult to conceive and implement also because of complex decision layers embedded in the EU. However, significant transformations have been pushed through several key reforms, particularly starting with the MacSharry reform in 1992. Core values of the PAC also trace back to the support of small scale familial farms. Yet this corollary to the initial CAP focus on food security progressively turned into increased support for large scale farms, the main winners of the subsidy policy, thus eroding the legitimacy of the program and exposing it to further criticism. Self-regulation, a key characteristic of the highly insular agricultural policy world, was further contested when trade organizations and organic and eco movements gained prominence.

A series of factors regarding technological agricultural progress, EU's political organization, and international pressures drove change in the CAP. External ones are related to global processes starting in the 1970s and accelerating in the 1980s, particularly the oil shock and increased trade liberalization culminating in the General Agreement on Tariffs and Trade (GATT), which later on became the World Trade Organization. Numerous internal factors added up to a main significant output: protectionist policies in the 1960s and 1970s led to a crisis of overproduction determining low prices and alarmingly decreasing returns for small scale farms. Moreover, technological advances leading to increased yields and less required workforce meant that member states' rural areas were at risk of being deserted or of transformation into poverty islands. Complementarily, the enlargement processes in the 1980s added Greece, Spain and Portugal, countries with substantial agricultural 
interests, the 1990s phase with Sweden, Finland and Austria, and the 2000s wave of Central and Eastern states, which further augmented the intricacies of the policy process. The CEE enlargement and its impact on agricultural policy was already taken into account during the European Parliament Copenhagen Summit in 1993 (Swinbank and Daugbjerg, 2006: 51). Moreover, budgetary concerns were raised by the member states supporting increased liberalization. Feindt (2018) points three discourse coalitions concerning agriculture. The productivist interest was dominated by farm organizations, France and Mediterranean countries. A multifunctionalist approach to rural areas rose from pressures from environmental and consumer NGOs and member states reliant on Pillar 2 (rural development), such as Finland and Austria. The market liberalist direction stemmed from industry groups, development groups, states with corporate agricultural sectors, particularly Denmark, the Netherlands and the United Kingdom.

The main element of the 1992 MacSharry reform, named after the respective Commissioner for Agriculture, represented the decoupling of price support and the introduction of direct payments. Some authors (Lenschow and Zito, 1988, in Lynggard, 2006; Swinbank and Daugbjerg, 2006) attribute the 1992 MacSharry reform to external factors, particularly the GATT. A re-evaluation of the impact of agricultural transformations on rural societies led to the introduction of multifunctionality as a more complex framing of solutions to development problems. With MacSharry, environmental concerns are mainstreamed into rural development policies. As the GATT tightened the window to enact the reform, and the consensus on interventionism within the agricultural policy networks was reached (Daugbjerg, 1999), its radical liberalization demands were suppressed.

The 1999 Fishler reform divided the CAP into two pillars, with a first representing a continuation of market interventionism, and a second focused on rural development policies. Fishler continued the PAC reform in 2003, with the introduction of eco-conditionalities and modulation, the latter signifying a response to criticism of some member states that allocations between Pillar I and Pillar II are too rigid. The same reform introduced the Single Payment Schemes, as well as a plan for transition for the incoming CEE member states. Modulation brought concerns of fragmentation in policy implementation among member states and diagnostics that the measures could translate into a 're-nationalization' of CAP (Swinbank and Daugbjerg, 2006: 56). The continuation of payment schemes in the most recent group of member states meant that the productivist character of the CAP was breathed with new life.

In regards to the 2013 reform, Greer (2017) concludes that although it introduced some changes, particularly the increased flexibility between pillars and the addition of new actors in the policy field, they can hardly constitute a 
shift from the exceptional character of agricultural policy. The key principles of the CAP are now market competitivity, convergence and capping. In the 20142020 programming period, two specific measures to support farmers (subsidies for income insurance and mutual funds) have been switched from Pillar 1 to Pillar 2, subverting the distinction between pillars and attracting criticism (Feindt, 2018:128). Moreover, as Daugbjerg and Feindt (2017: 8-9) point out, increased corporatization and financialisation of agricultural production extended the networks of upstream (such as financial institutions and chemical producers) and downstream interests (e.g. processors and distributors). In terms of its purpose, the EU rural development policy of the present programming period cannot be described as 'development' policy (Pelucha and Kveton, 2017: 9), as the emphasis still lies on sectoral agricultural tools, which cannot directly contribute to territorial cohesion objectives. The nine objectives presented by the European Commission in 2018 for the 2021-2027 period reiterate the CAP's focus on farm support, with increased focus on environmental issues.

Gorton et al. (2009) drew attention that the CAP arrived in Central and Eastern Europe with an unadjusted 'farm-centric' bias and no significant changes followed the negotiations with Agriculture Ministries in the New Member States. The authors' explanations point towards lack of administrative capacities in the NMS, on top of significant differences in regards to farm structures, as well as socio-economic convergence of their rural areas. Consequently, they argued that increasing direct payments through Pillar 1 could work against some policies in Pillar 2. Thus, the EU missed an opportunity to transform the CAP into an adequate pan-European policy. In the 2014-2020 period, Pillar 2 received 24.4 percent of the total funds (European Parliament, 2020) and the proposals tabled by the EC in 2018 and the Council Presidency in February 2020 for the 2021-2027 period advanced a 25 percent decrease in funding for Pillar 2 and just a 10 percent decrease to Pillar 1 . However, the economic recovery plan forwarded by the President of the EC in May 2020 contains an increased amount for Pillar 2.

\section{LEADER - from CAP compromise for prolonged productivism to mainstreaming in territorial policies}

Presently a key EU development policy, LEADER is described as an attempt to counter the declining state of rural areas with instruments aimed at stirring locally-oriented development based on several key principles: a bottomup approach, participation, partnerships, innovation; all channelled through Local Action Groups (LAG). It signified an intention of shifting policies from sectorial to territorial. The policy narrative portrays LEADER's alleged success 
as the factor leading to its mainstreaming in the 2014-2020 period within three additional funds under the umbrella of Community-Led Local Development. We will now look at the roots of the initiative, its underlying thesis - the shift from exogenous to endogenous development, and some main characteristics displayed during implementation.

The program can be traced back in two directions (Smith, 1995): one had been the need to counter the reforms of the CAP through a diversified approach; another represented the intention to directly stimulate financially more innovative regional and local thinking - thus, at least partially, bypassing member states' central governments. LEADER can be seen as an EU project of decentralization of national policies supported by the promotion of endogenous development, which places agency for change in local contexts. We can also note that the anti-state development projects were on the rise in the 1980s global context of fragmentation of development actions, when NGOs occurred as legitimate actors. Previously, global development actions and donor agencies have been dominated by economists, who searched for single causes for underdevelopment and prescribed monocausal solutions (Holcombe, 2014: 775).

The program's origin lies in the Commission of the European Communities paper of 1988, 'The Future of Rural Societies' (Moseley, 1995: 246). Projects developed in the 1980s, for example the French 'contrats de pays' and the projects of Scottish Highlands and Islands Development Board highly influenced the development of LEADER (Smith, 1995). The 1988 reform allowed the EC to introduce pilot interventions as 'Community Initiatives' and LEADER was rolled out in 1991 for a three-year period, then extended for another five years under the name LEADER II, when 887 Local Action Groups received funding. During the 2007-2013 cycle it became a part of Pillar 2 .

The 1988 report was informed by global contexts " $[\mathrm{t}]$ he Community is determined that its rural society should not gradually become a sort of technological Third World, condemned to a status of permanent underdevelopment" (Commission of the European Communities, 1988: 11). It indicates that the Commission was admittedly aware of various global systemic processes and their replication at different scales, including in its own policy territory. Although the report mentions some relations between rural and urban processes (e.g. migration), some aspects of the diagnostic are conducive to prescribed conservative solutions:

[t]he objective that should be pursued, in view of the pressures of modern development on rural society (first standard problem), is far less that of speeding up economic development in the rural areas than that of strengthened protection of the rural environment (1988: 8). 
A KNIFE TO A GUNFIGHT: ENDOGENOUS DEVELOPMENT THROUGH LEADER AS CONTRADICTORY POLICY PRESCRIPTION

The diagnostic continues by arguing that

[u]rbanization, industrialization, the development of transport infrastructures, the excessive pressure of tourism in certain areas, the scattered siting of new buildings (splinter development), and the occasionally reckless use of new techniques in all branches of activity, including farming, have combined to deface much of the countryside in the Community in the past few decades and continue to do so (1988: 16).

The report exhibits a theoretical cut of rural-urban flows and a distancing, faraway gaze of the analysts. The separation starts in the title with the categorization of 'rural society' as inherently opposed to an 'urban society', thus holistically different. Moreover, the colonial term 'indigenous potential' appears 14 times in the document, in an effort of making the rural legible for intervention.

Earlier critical accounts of the initiative focused, among others, on the amount of dedicated budget, as one author describes it, "at almost homeopathic doses" (von Meyer, 1997, in Ray, 2000: 165). Territoriality and ethical approaches to development are the key characteristics of the program. Against claims of a non-political character, rural development is brought clearly into the political domain. Ray (2000: 169) calls researchers to look beyond the 'endogenous development' official discourse - that solutions and resources for rural development lie in rural communities. For example, extra-local actors may use the endogenous approach as a shield for their locally applied agendas. Twenty-year-old case studies from Spain (Pérez, 2000) and France (Buller, 2000) already highlighted that local and regional administrations co-opted LEADER in their agendas, as well as the vision of LEADER as just another funding stream reinforcing the status-quo. Recalling the warning of Kovách that "[t]he technocratic model of the integration of Eastern-Central European rurality that underpins Phare and Sapard programmes actually represses the involvement of any other rural development actors" (2000: 186), we need to question if and how the practice further extended after EEC states joined the EU.

From their view as monofunctional areas dedicated to agriculture, rural areas have been designated as targets of a multifunctionality approach. An imprecise or even quite absent definition of a multifunctional rural area has survived for a surprisingly long period of time after it was introduced in policy language (Wilson, 2006). Tourism consisted the most opted for solution during the first LEADER phase. Taking into account the previously outlined context of rural policies, we could argue that tourism served as an attempt of exorcising the productivist character of rural areas, rendering their population less economically 
reliant on agriculture and preparing them for a different type of activity. It represented a project of increased museification of the rural since 2000 (Cejudo and Navarro, 2020) and a direction towards transforming it into a territory of consumption for urban populations.

The conviction that the implementation of LEADER represents a faithful mirror of policy intentionality spans a considerable width of the research body. Numerous studies enact a reification of the exogenous-endogenous schematic by focusing on evaluating its efficacy. Evaluation is a key policy cycle phase, particularly due to its forward looking gaze which legitimizes the approach in preparation for subsequent implementation. However, as High and Nemes (2007: 110) point out, LEADER evaluation does not endow local actions with a substantial role in the evaluation framework, maintaining instead an exogenous character because the centre needs to justify spending as effectively. It reflects a similar practice in housing research that Allen (2009) names elitist epistemology. Even though the initiative is focused on economic development, evaluation reports cannot asses its economic output and impact for the very reason that in terms of funding for economic activities, the measures are positioned under other axes. In the evaluation of the National Rural Development Program (Ministry of Agriculture and Rural Development, 2017), their impact assessment refers to results of measures from Axis 1 and 3, meaning that LEADER could be construed as an instrument for increasing effectiveness.

Rural studies generally celebrated the occurrence of LEADER as progress towards endogenous development and marked it as the abandonment of exogenous approaches. There are two complementary arguments to be made on this dichotomy. One lines up with the critical assessment of endogenous development initiated by Lowe et al (1995) and aptly expanded by Margarian (2013), while the other questions the functioning of a reformed endogenous approach, as long as it is based on a theory of growth. Several key concepts support this manoeuvre, most of them lying at a mezo level of conceptualization, where human capital, social capital, territorial governance and innovation, all add up to inform a territorial capital.

New Growth theory conceived in the 1980s, New Economic Geography born in the 1990s, and endogenous development, all could be assessed as conceptualization of what Harvey (2001) addresses as the capital's spatial fix. The Barca report (2009) convinced policy makers, along with numerous academics, that place-based policy approaches represent the solution to overcoming territorial inequalities. Endogenous development was presented as a shift from sectoral to territorial support. Yet, as Lowe et al. (1995: 95) put it, "the discourse of endogenous/exogenous development is inextricably rooted in geographical boundaries and this prevents a full understanding of the complex relations". 
Moreover, as described in the previous section, endogenous development through LEADER goes in parallel with the exogenous approach embedded in the CAP (Gkartzios and Lowe, 2019). There is thus a contradiction between the structural factors concretized through the CAP and the alleged autonomy awarded to local communities in rural development projects. The tight framework offered to local forces means that they are condemned to make the right choice. As Slee (1993: 51) highlights, "[m]ore often, 'endogenous' development is a means of achieving more effective development of a conventional type". The economistic colonization of rural development studies is shielded by what Lowe (2010: 319) describes as an empiricist departure initiated by researchers in the US. Most literature evaluates the penetration of the LEADER model, particularly that of its governance mechanisms, its implementation's hiccups, resistance or embracement. Positionality in the production of knowledge in rural policy would surely serve as key topic for future research.

As Lowe et al. (1995: 91) point out, and Margarian (2013) expands, the root of the conundrum branching out through European rural development policy is the lack of clear theoretical foundations for the occurrence of endogenous development. The introduction of endogenous development in European policy did not set out clear references to major restructuring processes taking place in the 1980s, such as deregulation, Western deindustrialization, or retrenchment of redistribution policies. With few exceptions, numerous studies of LEADER exhibit an empiricist nature and reiterate a debate translated from development economics, the exogenous-endogenous approach, situated in a growth paradigm. Margarian (2011) alleges that the endogenous approach is a normative reaction towards the perceived lingering malignant effects of previous exogenous interventions. The exogenous-endogenous debate makes sense when LEADER is officially portrayed as a development 'laboratory', as the two explanations are based on testing different variables. What the neoendogenous development perspective brought was a promotion of technological change - that is why innovation is key - and human capital from exogenous factors to endogenous ones. Along came a perspective on the governance of rural development, a form of development policy in practice that social scientists were late to acknowledge (Gkartzios and Lowe, 2019). As Navarro and Cejudo put it, the initiative is meant not to tackle spatial differences "but to create value around the uniqueness of these territories and the wellbeing of local actors" (2020: 302), which can be interpreted as the production of structures for a capital spatial fix through a recommodification of the countryside.

Thus, the endogenous approach to rural development can be traced back to the description of the problems that affected both rural economic output and its relation with urban counterpart, particularly the issue of overproduction and accompanying market changes. Territories are now pushed to take fate into their 
own hands, along with the responsibility for non-development, which no longer lays with the centre (Cejudo and Nvarro, 2020: vii). Mobilizing the countryside and activating local stakeholders have been key principles of LEADER (Dax et al. 2016: 57). Endogenous development has been extended in EU policies after the Barca report, which is based on endogenous growth theory and ignores exogenous forces (Avdikos and Chardas, 2016). Regardless of the effectiveness of the endogenous model, one of its key effects is the delegitimation of measures construed as exogenous.

The second, and wider, argument concerning the exogenous-endogenous debate refers to its rooting in the growth paradigm. When growth is established as the economic necessity and the core direction is that of unravelling new avenues for value production, new value can only be instantiated through exchange. Besides obvious ecological concerns, expanding growth structures solidifies present structures that concentrate value in urban areas, whose production modes are dependent on their hinterlands. Ye et al. (2020) argue that extractivism moved from global marginal spaces and is now a main feature of global capitalism, where control over flows is the basis of today's power. LEADER aims to solve the problems admittedly created by overproduction, while simultaneously opening up avenues for capital reterritorialization, thus perpetuating growth politics. In this manner, it represents a laboratory of refinement. Even green growth, the most recent wave of policy platforms around the world, is fraught with naive assumptions at best: an incoming decoupling of GDP growth from resource use is hardly supported by evidence (Hickel and Kallis, 2019). Although the degrowth literature focused so far on diagnostics and policy proposals, it lacks a supportive theory of the state (D'Alisa and Kallis, 2020), which would provide avenues for implementation and means of countering the present growth oriented politics. Moving beyond the critique of present rural development policies towards degrowth social models would require their confrontation with institutional power structures.

\section{Implementing the endogenous agenda: localism, participation, social networks}

The complexities of implementing the endogenous agenda through innumerable institutional layers readily convey its required top-down planning. Revelatory is the fact that some LAGs "see themselves as intermediaries rather than bottom-up partnerships" (Bosworth et al., 2016: 6). Geddes counters narratives that local partnerships reside at the core of new localisms, describing them as merely "a form of fragmented local crisis management" (Geddes, 1996: 797). People of marginalized rural areas find empowerment and participation enticing because they often feel left out of decision processes directly affecting 
them. In this context, underscoring the significance of local partnerships for endogenous development boxes out the critique of certain grand narratives. These development prescriptions would require the territories' inhabitants to be of the highest ethical order, while non-local economic actors determined to invest locally by a quest for a spatial fix, are exempted.

Participatory approaches in development projects had been cultivated during implementation in the Global South. The 1980s development principles reflected the emergence of verdicts that states are not adequate instruments of providing development at local levels. The answer has been a direction towards populist approaches to development through participation (Hickey and Mohan, 2004). While participation can augment independence of local actors in determining the goals and means of the process, its mainstreaming in development thinking applied a technicization that eschews wider structures of injustice (Hickey and Mohan, 2004: 11). Mainstream participatory methods inherently support the depoliticization of larger structures through efforts to relocate agency. Not dissimilar in ethos, LEADER's participatory framework alludes more to astroturfing than to a conveyed local will. The bottom-up approach is pushed from above through nudging, yet sold as output. It shifts responsibility at local levels, both in terms of diagnosis, as well as solutions. As Margarian (2013: 5) points out, participation is deemed essential because it increases the effectiveness of the action. It is no wonder that professionalized external consultancy firms often play a crucial role in setting up the initial stages of LAGs actions.

If there is some conceptual form of power relations to be tackled through participation in LAGs, the only internal one in the imagined communities at play refers to conservative patrimonialistic economic actors and progressive ones. Complementarily, other power relations at stake concern the local against the state in terms of governance practices, and the local and global in economic practices. In this case, the role of nudging is to disrupt existing social networks in order to support the creation of new ones suited for embeddedness in economic structures allegedly new to the area. If we scrutinize the economy of participation - who has the resources to participate and on what terms - we discover that very few disposes of the required means. That the very poor are not directly targeted is certain, but even the presumed middle-class encounter problems in benefiting from participatory actions of LEADER. The ex-post evaluation of LEADER II underscored that "[i]ronically, the complexity of programmer delivery acted as an invisible hand in favour of complementarity and for selecting the most committed project promoters" (Österreichisches Institut für Raumplanung, 2006: 232). It can be argued that the result is not 'ironic', but planned and expected. Barke and Newton (1994) indicate that LAGs that already possessed a form of bureaucratic experience held an advantage, a 
fact acknowledged later on by the LEADER II ex-post evaluation (Österreichisches Institut für Raumplanung 2006: 145). Behavioural changes are deemed significant gains from the first two iterations, "[t]he successful implementation of the LEADER method was a success in itself, for it meant behavioural change" (id., p. 225).

As Somers (2005) warns in her acid critique of the conception and uses of social capital, sociologists should oppose the advent of social capital which is nothing more than the economists' Trojan horse attempting to marketize the social. "The breadth of the terrain on which rational choice theorists set their sights should not deceive. This was in no way a genuine venture into the theoretical world of the noneconomic; rather, this was the project of what Gary Becker called an 'economic imperialism"' (Becker in Swedberg, 1990: 39) Social capital comes with an anti-statist, anti-rights, and anti-institutional character (Somers, 2005: 13). Power relations are also evicted from the conceptual schematic.

Conceptualization of social capital in LEADER literature is so weak that some authors cannot seem to allocate it a clear role: "[v]iewing social capital as both a prerequisite for and outcome of applying the LEADER approach is not contradictory" (Marquardt et al., 2012: 401). The same analysis suggests a glorification of local partnerships where public actors are set aside:

[i]n Romania, hierarchical political administrative structures, especially with the leading role of the mayors and the strongly positioned county councils, are therefore an obstacle to LEADER [...] Generally, local actors seem to lack initiative and need leadership. Passivity strengthens the traditional political institutions and inhibits better governance. Overcoming this deeply rooted heritage of the socialist era can hardly be achieved by capacity building in the pre-implementation phase; rather, it is a long-term process. (Marquardt et al. 2012:422).

As if building 'better' social capital would, alas, solve the LEADER implementation problem, a view which renders the whole initiative, both figuratively and literally, as a multi-level marketing scheme selling entrepreneurship as solution.

Numerous authors point out that bottom-up, participation, and (especially) innovation are buzz-words. Yet they not only survive, but are rolled over in the next policy cycle. Innovation remained a long lasting key policy prescription, even though it is regarded as a fuzzy concept. According to the LEADER II expost evaluation, 
[m]ost groups embraced a pragmatic interpretation of innovation. Innovative meant "new to the area"' and compared to the first iteration, space for innovation was reduced due to increased national bureaucratization. (Österreichisches Institut für Raumplanung, 2006: 165).

In practice there was no strict attachment to the innovation requirement. One EC official said that it was not innovation that most rural areas needed, but just "well managed rural development". In the daily practice, "innovation became a synonym for complementarity." (id., p. 165). Then why is there so much emphasis on the troubled concept? It seems that its main pedagogical role is to urge the abandonment of the 'old' exogenous thinking.

\section{Relocal methodology}

The article will further lay out some key findings on the implementation of the endogenous agenda. The empirical data comes from the Relocal.eu research project focused on assessing spatial justice through case studies. I undertook the field research in 2018-2019, which entailed 20 interviews, mostly with public employees in the area, and two group discussions with stakeholders surrounding Mara-Natur Local Action Group in the county of Maramureș, in North-western Romania. The interviews' main themes focused on perceptions of spatial justice, instruments for development and cohesion, the functioning of the LAG, and the sense of local autonomy. The key research topic represented the assessment of spatial justice perceptions. This data has been complemented with a review of grey literature ranging from local, regional and national to EU level publishers.

\section{Romania - context and agro-rural-territorial policies}

Romania is the EU state with one of the highest ratios of rural population - 9 million rural inhabitants in 2018 out of a total of 19.5 million, making it a key target for EU-led rural interventions. The country holds a record for emigration rate, mostly to older EU states, both from rural and urban areas, which raises the question of who decided to stay or, rather, got stuck in rural areas. Specifically, who would be available for development projects and what type of development would they favour? Small plots represented quintessential assets in coping with austerity policies in the 1980s by supporting recently urbanized relatives, but also during deindustrialization, mass layoffs and return 
to the rural in the 1990s, as well as in the context of general low-wage policies from 2000s onwards. Most familial agricultural practices are subsistence oriented. According to EU statistics, Romanian farming is deeply unequal, as "nine in every ten farms (91.8\% or 3.1 million farms) were smaller than 5 ha, but the $0.5 \%$ of farms of 50 ha or more in size farmed one half (51.1\%) of all the UAA in the country" (Eurostat, 2018: 19). Basically, it is a two tier farming system. Land registration is not completed, which deters the circulation of land on the market - owners could benefit from subsidies, but, on the other hand, it would support a policy of enclosures (Amin, 2017). Land grabbing is, nevertheless, a common occurrence, and one of the core explanations for tenure duality. Moreover, candidate countries had to dismantle barriers protecting their agriculture from subsidized Western agriculture, leaving farmers in precarious positions. Besides administrative decentralization, a significant contribution to inequality comes from national territorial policies such as the institution of metropolitan areas as soft policy spaces or the territorial planning instrument R02035, which envision a polycentric development model (Ministry of Regional Development and Public Administration, 2015). Analysing European Quality of Life Survey data, Shucksmith et al. (2009) concluded that urban-rural differences in the 12 richest EU states are minimal, but the difference was substantially higher in poorer countries, such as Southern MS and the NMS. If LEADER was originally conceived for the issues faced by Western European rural areas, principles have not been adjusted for states with different situations.

\section{A local application of endogenous rural development policy: views of public partners in a Romanian LAG}

Romania underwent drastic deindustrialization in the 1990s and 2000s. The Maramureș mining industry employed around 30,000 people at its peak and has thus experienced dramatic changes when the sector shut down. Depopulation is country-wide specific, yet county demographic projections are even bleaker at $-10.6 \%$ in 2030 and $-33,9 \%$ in 2060 (Institutul Național de Statistică, 2017). In 2016-2017 the county had, at 65\%, the country's highest ratio of employees earning the minimum wage (Patronatul Investitorilor Autohtoni PIAROM, 2018). Research on territorial inequality points that even though the North-western region is the least affected by poverty and social exclusion, the region is highly polarized around the most developed county, Cluj (Ministry of Regional Development, 2017). The LAG's territory reproduces the country-wide territorial inequality. The suburban villages neighbouring the county capital are substantially more developed compared to their furthest 
counterparts. Just around $12 \%$ of the total population is employed predominantly in the three villages and the town surrounding the city of Baia Mare (MaraNatur LDS).

The Romanian Government initiated LEADER with a three-year delay during its fourth iteration in the 2007-2013 programming period and 239 Local Action Groups became operational in its subsequent programming period. During the PAC Health Check in 2008, Romania adopted the position of maintaining the status quo. Based on each of their Local Development Strategy, they open calls and select small-scale projects to be funded with an average of several tens of thousands of Euro. Social services provision reflects the wider trend, as they have already been externalized or relegated to a high degree towards NGOs. Welfare is now expected to be carried out through project-based initiatives, as well as through external funding as much as possible. In the locality's villages with poor Roma populations, NGOs managing Norwegian Grants implement social inclusion projects.

Mara-Natur was formed in 2011 at the initiative of the municipality of Baia Sprie, a small city in the county of Maramures, North-West Romania. The five communes in its componence catalogued as poor according to the Local Development Human Index, are located in the Southern and South-eastern parts, the farthest from the county capital Baia Mare and from any other major city. The population density of the territory accurately reflects it: the less dense the population, the poorer the respective area. The economic disparity of MaraNatur's territory is amply documented in its LDS, revealing that most economic activity takes place in the vicinity of Baia Mare. The other city in the region, Târgu Lăpuș (population 12.000) is practically surrounded by villages associated in Mara-Natur. As a relatively remote, as well as actively de-developed area primarily through the cessation of mining exploitation, its development parameters are highly sensitive to upper-level political decisions. As a commune mayor explains, attracting external funding is a main motivation for joining the LAG: "[w]e succeeded. We had to. [...] Because it is another easier funding source on European funding". Other stories depict mayors who were particularly sceptical or not interested - with the explanation that they are either too exhausted or anxious because of extra responsibilities. In the end, it appears that discovering the opportunities, costs, as well as limits, lead most of them to view the membership to the LAG as a positive. One stakeholder puts it simply that "there was a strategy creator and an explanation creator towards authorities for why it is good" and the money stood as bait to overcome reluctance. Initially, the idea of LEADER arrived in the area through presentations prepared by consultancy firms who described it as opportunity to access funding. As interviewees pointed, similarly to numerous other LAGs, it assembled around public actors. 
In the first stages, Mara-Natur supported each of the 18 local administrative units to apply for small funds. Recently, its calls for applications shifted focus towards the development of small businesses and entrepreneurial development. According to the 2016 LDS, the objectives regard the conservation and promotion of natural and cultural heritage, increasing the area's economic output, supporting social equity through social services, and developing the area's good governance. As the Mara-Natur team representative underlines, "LEADER is complementary to the large NPRD. Mara-Natur's funding objectives specifically did not include infrastructural projects because town halls can access other designated funding". Indeed, LAGs are not singular development instruments, they exist in a complex and thick layer of myriad initiatives unfolding in parallel. Besides other agricultural and rural programs, the Ministry of Development offers a National Program for Local Development. With every funding opportunity comes a requirement to conceive planning documentation, which coexist with each territorial administrative unit's own strategy, as well as county, regional, and national level. Over-planning is a disempowering mechanism which absorbs scarce and valuable resources at local level, particularly in project-oriented funding system. Moreover, local administrative autonomy is stifled by low financial autonomy. Interviewees point the lack of ministerial coordination in development plans. Often, reverse-thinking leads to adopting legislation to prevent infringement without checking the capacities of local administrations to solve particular issues, such as environmental ones. Some regulations actively impede infrastructure development because of technical evaluation which excludes forms of territorial arrangements such as scattered villages. And some technical solutions, although superior, are not legally allowed, for example using sewage pits produced in the area, although the producer exports them to mountainous areas in Germany and Austria. At the end of the whole series of efforts, as the LAG representative describes, lies the final beneficiary, who is, more often than not, a regular person adapted to subsistence livelihood and who finds the price of overwhelming bureaucracy as too costly to even bother.

As recounted by public administrators, the transfer of responsibilities from central to local levels is not properly coupled with the assurance of adequate funds for responding to these obligations; therefore, they all acknowledge the need to apply for alternative financial resources. Yet again, some are more capable of writing competitive projects, others dispose of funding for externalization. For richer communes, Mara-Natur is the cherry on top, just another opportunity for attracting external funding, while for poorer ones it turns into a source of frustration: funds are symbolic relative to their needs, and the administrative effort too costly. At a larger scale, the increased bureaucratic procedures and the need to co-finance the funded initiatives favour by design the public administration 
and the more experienced private economic agents, while they discourage the poor, who have fewer incentives to apply for funds for their plans. Even for LAUs, particularly the poorer ones, a 2 percent mandatory co-funding rule might be an issue. Because there are numerous mayors involved in LAGs, the ministry cannot politically refuse to support them. But, as respondents say, there are pressures from meat producers or others to direct increased funding to them. They assess the state level agro-rural policy as uncritical towards EU policy, where it acts as translator because changes are not adequately discussed with beneficiaries and deadlines are short. Moreover, the Ministry of Agriculture does not assume long-term commitment during debates on the next programming period for this rural policy instrument, which has already created a class of local rural development specialists - around 1000 in LAGs only. This concern unravels shaky sustainability of the whole program. It is unfortunate, according to interviewees, as LEADER does contribute to achieving spatial justice through more equitable measures than the national ones.

In the absence of local capacity to engage in project application and implementation, local authorities gain significant support roles, as interviewees conclude. The situation seems widespread, a study covering 20 villages in a southern county (Mihalache, 2016) revealed that accessing development projects turns into a prerequisite in attracting future funding, due to gaining administrative competences. Local authorities might end up signing partnerships, but the partners might not fulfil the project indicators and everything will fall back to the public administration, particularly financially, as it has happened - according to an informant:

[w] hy should I, as local authority, contract consultancy services, as long as the responsibility for the funding contract remains exclusively with the beneficiary?

[...] Because, although for colossal money and in the moment of verification and audit, the consultant is free from obligation, no responsibility.

Interviewees acknowledge networking as an added-value of LEADER due to the LAG's meetings which represent opportunities to exchange ideas.

Sometimes, calls for projects need to be rescheduled because no applications are submitted. From the management perspective it is not an inherent issue, yet even an indicator of perseverance, while others directly conclude that "the fact that people do not apply for funding should make us think". On the other hand, insufficient will of association between inhabitants is considered an important hindrance to local development and is bluntly stated in the LDS. EU programs attempting to induce rural economic cooperation after the socialist Agriculture Production Cooperatives have been dismantled is more than ironic. Opening up 
guest houses has been a success, yet there are currently no funding lines for this demand - an underlining of the lack of autonomy, or lack of support for development - instead, climate and innovation measures appear now to be the measures eating up a substantial part of the rural development budget, which is not deemed useful for this area: "you should give 40 per cent on innovation, environment and climate change, where we don't have experience, we don't even know what we want, we don't even know what the word 'innovation' means...". A note here: while the area's environment will continue to suffer from previous poly-metal extraction, mining conservation is a governmental responsibility.

Attracting applicants is challenging because of co-funding requirements added up to the lack of bureaucratic experience, as well as to the impediments in 'animating the community' - while work-led migration sucked away a sizeable chunk of the working-age population. Thus, the idea of turning the LAG into a local scale management authority, a 'mini-NRDP', represents one 'temptation' for LAGs which is to be avoided if a LAG desires to actually work organically, as intended. It would be 'the easy way out', according to a representative. Petrescu (2015) encountered strikingly similar confessions during interviews with representatives of Romanian LAGs. Why is this apparent trick so out-spoken? Because fund absorption is the prime political objective, whereas ideational agendas regarding principles of rural development are secondary at best. From this perspective, LAGs are Mini-EUs in a structure resembling a Matryoshka doll opening up European Commission - Romanian Government - Regional RDP Agency - LAG. Keeping in mind that fund absorption is a key evaluation indicator, financing projects that 'just work' from an administrative point of view is an alluring prospect. Thus, autonomy of LAGs is technically guided towards a certain result and community needs found on the ground have to comply.

Public administrators are presented with numerous offers of accessing the competitive field of development projects, either through national or European programs. Yet, as respondents point out, they are not even supplied with the right tools and resources to counter the centrifugal effects of neighbouring urban growth poles. A problem is that even if all the prescriptions are followed, chances of achieving a form of development drop when exposed to larger economical structures - no integration to local and regional chains, weak infrastructure, tough competition on the market with both national and international mammoth actors, on top of increased polarization already exhibited and promoted by the government which drives any newly discovered resources as much as possible to few regional cities.

Who do the EU policies bear in mind when devising new policies? Respondents underlined that it feels like numerous core concepts and policies, particularly in rural development, are designed with Western European areas in 
mind. For example, the looming 'innovation' and 'climate' thematic areas are regarded as simply inadequate for most of the Romanian rural parts for a couple of reasons. One would be that pollution has been reduced simply as a result of deindustrialization. The other is that 'innovation' requires significant academic activity, which here is at best insufficient, or simply unavailable. The present gap between the material realities of Romanian rural areas and Western rural areas is much wider than the EU-wide official vocabulary implies. As the LAG representative asserts, the introduction of sewage in some villages could be considered an innovation in the respective setting. So, at the moment, LEADER seems to be applied in Romania as the Romanian villages had merely experienced the same development trajectories as Western villages.

Over-bureaucratization and rigidity are certain issues, as mentioned by most LEADER evaluation studies (Navarro and Cejudo, 2020: 301), which both affect local autonomy. For example, even if the LAG would decide that they want to adopt a more equal territorial distribution of funding, regulation regarding competition would prevent them from doing so. Overall, the present funding management regulations are not just overbearing, but they turn into an instrument of control. The reason is the lack of any real guidance offered during the project cycle and the almost exclusive focus on meticulous verification and evaluation. On top, rules change much too frequently during project implementation. However, while it is expected that regulation suffers adaptations, the speed and complexity of the unexpected changes provokes a surplus layer of uncertainty and stress. The end result is a general decline in enthusiasm for potential applicants to EU funding. The issue of detrimentally excessive focus on control, instead of guidance and collaboration, is also visible when local needs are not taken into account at central levels. Drafts of nationally relevant guides for future funding are not open to the public, and most local knowledge, however well-documented that is, is not really taken into consideration at central levels, informants mention. The manoeuvres could be interpreted as a result of insidious top-down political power schemes, but they might partly be a side-effect of a rather clear process: the lack of assumption of responsibility of the national institutions involved in the process. Concretely, for example, EU regulations are seldom adequately transposed in intelligible guidelines which can easily be applied by funding recipients. The question of why the relevant ministries hastily adopt and implement EU regulations without significant negotiation with the European Commission, as other states often do, needs answers from other sources. Yet, the issue reverberates and amplifies at lower levels. From this point of view, interviewees portray a colonymetropolis relation between the Romanian state and the EU institutions, as orders from above are simply being obeyed. 
Personnel and competences are a central concern to people involved directly and indirectly in Mara-Natur. Autonomy in spatial justice processes is unattainable without the required human power able to steer it through development projects. But the whole set of procedures launched by the European funding schemes favours by design the externalization of human resources to private consultancy firms, who bear no accountability. Thus, instead of becoming a stone at the foundation of local autonomy and spatial justice, it shatters them. Consolidated institutions would be better equipped to act towards a more equal territorial development. Concretely, if local public administrations could permanently employ motivated teams of specialists in funding management and other fields related to territorial development, their capacity to roll development projects would greatly improve. The LAG would better serve the territory by obtaining the required support to hire people who would bring the necessary expertise. For example, respondents demand a permanent architect and territorial planner who would serve those town-halls who cannot afford to hire them independently.

For the local actors, LEADER so far constitutes an exercise in administrative capacity to attract external funding, develop projects, while interacting at a different and novel scale. Practically, the LAG operates as a localized intermediary management organism in the EU funding distribution chain: it opens calls and selects small-scale projects according to its LDS. Whether LAGs are supposed to become self-supported after a while is unknown. Besides attention to the implementation of the local development strategy, management teams have to consider the LAG's preservation by carefully pacing activities during the seven-year funding cycle. The county council has recently joined the four LAGs operating in the county as partner and its financial contribution is regarded as significant in supporting the organizations to overcome potential funding interruptions. Interviewees are concerned that increased modulation between the CAP pillars would be a crushing blow to the LAGs, few would survive. Overall, this potential direction is in direct opposition to the needs and requests formulated through the LAGs. Higher degrees of financial autonomy and higher funding levels are deemed necessary to further the LAGs impact and benefits on local development. LAGs' managerial work needs pin-point precision to successfully attract the meagre, yet much-needed funding, while respecting the program's principles and strict conditionalities. The incurred cost supported by actors for the pedagogical process involves the assessment of benefits and the adaptation of institutional thinking to a new format. The cost of applying a highly complex format designed for skilled administrative personnel to de-developed areas deficient in administrative capacity is unknown, and without clear long-term scope of the whole program, it is unpredictable. 
A KNIFE TO A GUNFIGHT: ENDOGENOUS DEVELOPMENT THROUGH LEADER AS CONTRADICTORY POLICY PRESCRIPTION

\section{Conclusions}

The brief incursion into the CAP's history set the scene to evaluate the drift between the formation of policy principles. Analysis of LEADER policy characteristics, particularly its endogenous approach, showed that its origins lie in an economistic view of development which rearranges rural development options in a tight framework meant to suit wider policy agendas. This article examined the 2014-2020 implementation through a case-study focused on perceptions of public actors involved in a Local Action Group in North-western Romania. LEADER is portrayed as intention of spurring locally identified potential growth factors. What the overview of the CAP conveys is that this example of endogenous development has been born, at least partially, as reaction to structural factors, ranging from global geopolitics to EU internal politics, not from direct concern with effects of uneven development. Initially introduced as laboratory for rural renewal, LEADER constitutes a compromise intended to sustain the productivist character of agricultural policy in front of critique stemming from a wide range of actors. In this sense, it is not a novel approach in itself, but a novel application of an already instituted economic system.

The case-study reveals that resource-poor rural areas are bestowed with the impossible task of kick starting sustainable small scale economic development without the adequate resources for financial and administrative economic participation, while navigating a convoluted bureaucratic system. Rural public administrations, often the sole actors with administrative capacity in their area, are deemed conveyors and risk-takers for development projects, particularly in public infrastructure, a required element for any subsequent economic project. Their required involvement in the program without support for increasing administrative capacity through investment in personnel, reflects LEADER's attempt of bypassing state institutions. Innovation, a core LEADER principle, alludes to smart solutions for improving an already working economic structure. In the present dire context, it constitutes an unnecessary bureaucratic burden in attraction of funding. Exogenous factors, which are the initial determinants for the area's dereliction, and redistribution, are regarded as quintessential for improvement. In Romania, LEADER runs in a policy ecosystem flooded with exogenous and uneven development planning, be it most of the CAP or the national growth-pole territorial strategy. Efforts should inherently tackle at their core the centrifugal forces which agglomerate resources in urban centres.

As any large-scale amply funded policy with substantial legitimacy, LEADER is mandated to be successful. But the long-term life of the program is unclear. No 
clear pathways towards the type of emerging (rural) society, its economic structure, or its relations with urban counterparts, are outlined. The incentives for people and institutions to assemble in a LAG according to these principles, if no funds were attached, are not elucidated. Crucially, if the initiatives constitute examples of good practice, how could non-beneficiaries of financial support follow through? Endogenous thinking still runs largely uncontested because its allusions of empowerment and autonomy are concrete yearnings. The LEADER framework skilfully answers to empowerment demands by presenting entrepreneurship as empowerment instrument and an increased competitive structure. It promises a renaissance project where peripheral positions do not ontologically stand as hindrance and actors appear if not equal, at least as belonging to the same field. These features place rural actors in the high risk position of failing once again to achieve development. Redistribution necessities, to which LEADER meagrely contributes, trump the need, and available resources, for overt contestation of principles and procedures. Substantive redistribution is off the table, as it would run against the mechanisms of the capital's spatial fix.

While the LEADER configuration deems local knowledge and community building as essential stepping stones in tackling uneven development effects, it fails to properly acknowledge (and even discursively obfuscates) the necessary resources and capacities - as well as the overwhelming influence of outside factors - and even geopolitical contexts (such as East-West histories), mandatory for the production of spatial justice. It arrived as a tool for governing rural populations as 'surplus population'. The economistic view of development offered through LEADER acts as mechanism for coping with prolonged austerity without actually tackling its roots. Overall, the program represents an instrument for depoliticization, a mechanism of reshuffling institutional memory which redraws territories of responsibility and blurs macro socio-economic contexts. LAGs are bestowed with technical managerial roles deemed to steer free-floating areas. If unfettered economic growth continues as main development principle, with few exceptions, areas affected by uneven development are at risk of maintaining their present position. Emphasizing participation and the consumption of social networks for the program's implementation highlights both the different local perception of the problems' origins and the policy intention of re-encapsulating solutions along with increased local responsibilities. However, neither principles, nor procedural propositions, seem to reduce widening territorial inequalities. Ultimately, LEADER represents a pedagogical exercise in uneven development. 


\section{A KNIFE TO A GUNFIGHT: ENDOGENOUS DEVELOPMENT THROUGH LEADER AS CONTRADICTORY POLICY PRESCRIPTION}

\section{REFERENCES}

Allen, Chris (2009). The Fallacy of "Housing Studies": Philosophical Problems of Knowledge and Understanding in Housing Research. Housing, Theory and Society. Volume (26)1: 53-79.

Almstedt, Åsa, Patrick Brouder, Svante Karlsson, Linda Lundmark (2014). Beyond post Productivism: from Rural Policy Discourse to Rural Diversity. European Countryside. Volume 4: 297-306.

Amin, Samir (2017). The Agrarian Question a Century after October 1917: Capitalist Agriculture and Agricultures in Capitalism. Agrarian South: Journal of Political Economy. Volume 6(2): 149-174.

Avdikos, Vasilis, Anastassios Chardas (2016). European Union Cohesion Policy Post 2014: More (Place-Based and Conditional) Growth - Less Redistribution and Cohesion. Territory, Politics, Governance. Volume (4)1: 97-117.

Barca, Fabrizio. (2009). An Agenda for a Reformed Cohesion Policy, a Place - based Approach to Meeting EU Challenges and Expectations. Independent report prepared at the request of Danuta Hubner, Commissioner for Regional Policy, EU.

Barke, Michael, Michael Newton (1994). A new rural development initiative in Spain: the European Community's 'Plan LEADER'. Geography. Volume (79)4: 366-371.

Bosworth, Gary, Ivan Annibal, Terry Carroll, Liz Price, Jessica Sellick, John Shepherd (2016). Empowering Local Action through Neo-Endogenous Development; The Case of LEADER in England. Sociologia Ruralis. Volume 56(3): 427-449.

Buller, Henry (2000). Re-creating Rural Territories: LEADER in France. Sociologia Ruralis. Volume 40(2): 190-199.

Cejudo, Eugenio, Francisco Navarro (eds.) (2020). Neoendogenous Development in European Rural Areas Results and Lessons. Cham, Switzerland: Springer.

Commission of the European Communities (1988). The future of rural society. Bulletin of the European Communities. Supplement 4/88 (Brussels, CEC).

D'Alisa, Giacomo, Giorgos Kallis (2020). Degrowth and the State. Ecological economics. Vol 169: 1-9.

Daugbjerg, Carsten (1999). Reforming the CAP: Policy Networks and Broader Institutional Structures. Journal of Common Market Studies. Volume 37(3): 407-28.

Daugbjerg, Carsten, Peter H. Feindt (2017). Post-exceptionalism in public policy: transforming food and agricultural policy. Journal of European Public Policy. Volume 24(11): $1565-1584$.

Dax, Thomas, Wibke Strahl, James Kirwan, Damian Maye (2016). The Leader Programme 2007-2013: Enabling or Disabling Social Innovation and Neo-Endogenous Development? Insights from Austria and Ireland. European Urban and Regional Studies. Volume 23(1): 56-68.

European Parliament (2020a). The Common Agricultural Policy in figures. Available at: https://www.europarl.europa.eu/factsheets/en/sheet/104/the-commonagricultural-policy-in-figures [Accessed on 15.06.2020]. 
Eurostat (2018). Agriculture, Forestry and Fishing Statistics. Available at: https://ec.europa.eu/eurostat/web/products-statistical-books/-/KS-FK-18-001 [Accessed on 15.06.2020].

Feindt, Peter F (2018). 'EU agricultural policy'. Chapter in Hubert Heinelt, Sybille Münch (eds.) Handbook of European Policies Interpretive Approaches to the EU. Cheltenham: Edward Elgar Publishing.

Geddes, Mike (1996). Tackling Social Exclusion in the European Union? The Limits to the New Orthodoxy of Local Partnership. International Journal of Urban and Regional Research. Volume 24(4): 782-800.

Gerber, Julien-François (2020). Degrowth and critical agrarian studies. The Journal of Peasant Studies. Volume 47(2): 235-264.

Gorton, Matthew, Carmen Hubbard, Lionel Hubbard (2009). The Folly of European Union Policy Transfer: Why the Common Agricultural Policy (CAP) Does Not Fit Central and Eastern Europe. Regional Studies. Volume (43)10: 1305-1317.

Gkartzios, M. and Lowe, P. (2019). Revisiting Neo-Endogenous Rural Development. In: Scott, M., Gallent, N. and Gkartzios, M. (eds.) The Routledge Companion to Rural Planning. New York: Routledge.

Greer, Alan (2017). Post-exceptional politics in agriculture: an examination of the 2013 CAP reform Journal of European Public Policy. Volume 24(11): 1585-1603.

Harvey, David (2001). Globalization and the "Spatial Fix". Geographische Revue. Vol (2).

Hickel, Jason, Giorgos Kallis (2019). Is Green Growth Possible? New Political Economy. Volume 25(4): 469-486.

Hickey, Samuel, Giles Mohan (eds.) (2004). Participation: from Tyranny to Transformation? Exploring New Approaches to Participation in Development. London: Zed Books.

High Chris, Gusztáv Nemes (2007). Social Learning in LEADER: Exogenous, Endogenous and Hybrid Evaluation in Rural Development. Sociologia Ruralis. Volume 47(2): 103-119.

Holcombe, Susan H (2014). Donors and exogenous Versus Endogenous Development. Development in Practice. Volume (24)5-6: 750-763.

Institutul Național de Statistică (2017). Proiectarea populației României în profil teritorial la orizontul anului 2060. [Projection of Romania's population in territorial profile at the horizon of year 2060].

Kovách, Imre (2000). LEADER, a New Social Order, and the Central- and East-European Countries. Sociologia Ruralis. Volume 40(2): 181-189.

Lynggaard, Kennet (2006). The Common Agricultural Policy and organic Farming. Wallingford: CABI Publishing.

Lowe, Philip, Jonathan Murdoch, Neil Ward (1995). Networks in Rural Development: Beyond Exogenous and Endogenous Models. In Jan Douwe van der Ploeg, Gert van Dijk (eds.), Beyond modernization. The Impact of Endogenous Rural Development. Assen: Van Gorcum.

Lowe, Philip (2010). Enacting Rural Sociology: Or what are the Creativity Claims of the Engaged Sciences? Sociologia Ruralis. Volume 50(4): 311-330. 


\section{A KNIFE TO A GUNFIGHT: ENDOGENOUS DEVELOPMENT THROUGH LEADER AS CONTRADICTORY POLICY PRESCRIPTION}

Mara-Natur Local Action Group. Local Development Strategy 2016-2020. Available at: https://www.maranatur.ro/index.php/strategia-2016-2020/strategia [Accessed on 15.06.2020].

Margarian, Anne (2013). A Constructive Critique of the Endogenous Development Approach in the European Support of Rural Areas. Growth and Change. Volume 44(1): 1-29.

Marquardt, Doris, Judith Möllers, Gertrud Buchenrieder (2012). Social Networks and Rural Development: LEADER in Romania. Sociologia Ruralis. Volume 52(4): 398-431.

Mather, Alexander S, Gary Hillb, Maria Nijnik (2006). Post-Productivism and Rural Land use: Cul De Sac or Challenge for Theorization? Journal of Rural Studies. Volume 22: 441-455.

Mihalache, Flavius (2016). Coordinates of Rural Development in 20 Villages in the Southern Part of County Arges. Journal of Community Positive Practices, Volume 16(2): 56-69.

Ministerul Agriculturii și Dezvoltării Rurale (2017). Ex-post evaluation study of the national rural development programme 2007-2013. Available at: http://madr.ro/docs/dezvoltare-rurala/studii/Ex-post-evaluation-of-NRDP2007-2013-EN.pdf [Accessed on 15.06.202].

Ministerul Dezvoltării Regionale și Administrației Publice (2015). Strategia de dezvoltare teritorială a României; România policentrică 2035; Coeziune şi competitivitate teritorială, dezvoltare şi şanse egale pentru oameni. [Romania's Territorial Development Strategy; Polycentric Romania 2035; Cohesion and Territorial Competitivity, Development and Equal Chances for People].

Ministerul Dezvoltării Regionale și Administrației Publice (2019). Raport privind starea teritoriului România 2017. [National Report on the State of the Territory Romania 2017).

Moseley, Malcolm J (1995). Policy and Practice. The Environmental Component of the Leader Programme, 1992-94, Journal of Environmental Planning and Management. Volume 38(2): 245-252.

Österreichisches Institut für Raumplanung (2006). Ex-post Evaluation of the Community Initiative LEADER II Final Report Volume 1: Main Report. Commissioned by: European Commission DG Agriculture, Unit A.4.

Patronatul Investitorilor Autohtoni PIAROM (2018). Studiu privind dinamica pieței muncii la nivelul principalelor industrii angajatoare din Romania în perioada 20162017. [Study Regarding the Labor Market Dynamic in the Main Employing Industries in Romania in the Period 2016-2017].

Pelucha, Martin, Viktor Kveton (2017). The role of EU Rural Development Policy in the Neo-Productivist Agricultural Paradigm. Regional Studies. Volume 51(12): 1-11.

Pérez, Javier Esparcia (2000). The LEADER Programme and the Rise of Rural Development in Spain. Sociologia Ruralis. Volume 40(2): 200-207.

Petrescu, Claudia (2015). Association and Cooperation in Romanian Rural Areas - the LEADER Experience. Journal of Community Positive Practices. Volume 15(2): 2842. 
Ray, Christopher (2000). The EU LEADER Programme: Rural Development Laboratory. Sociologia Ruralis. Volume 40(2): 163-171.

Romer, Paul M (1994). The Origins of Endogenous Growth. Journal of Economic Perspectives. Volume (8)1: 3-22.

Shucksmith Mark, Stuart Cameron, Tanya Merridew, Florian Pichler (2009). UrbanRural Differences in Quality of Life across the European Union. Regional Studies. Volume (43)10: 1275-1289.

Slee, Bill (1993). Endogenous development; A concept in search of a theory. Options Méditerranéennes, Sér A /no 23.

Smith, Andy (1995). Going Beyond the Democratic Deficit: The European Union and Rural Development in Networked Societies. Regional \& Federal Studies. Volume 5(1): 45-66.

Somers, Margaret R (2005). Let Them Eat Social Capital: Socializing the Market Versus Marketizing the Social. Thesis Eleven. Number 81: 5-19.

Swinbank, Alan, Carsten Daugbjerg (2006). The 2003 CAP Reform: Accommodating WTO Pressures. Comparative European Politics. Volume 4:47-64.

Wilson, Geoff A (2006). Multifunctional Agriculture. A Transition Theory Perspective. Wallingford: CABI. 